\title{
Pluripotente stamceller mot lang QT-syndrom
}

\author{
Ny forskning tyder på at lang QT-syn- \\ drom kanskje kan behandles ut fra \\ den enkelte pasients celletype.
}

Medfødt lang QT-syndrom er en familiær rytmeforstyrrelse karakterisert av forsinket elektrisk reoppladning av hjertemuskelcellene. Årsaken er mutasjoner i gener som koder for ionepumper. Tilstanden kan medføre plutselig død hos unge voksne. Mutasjonen finnes hos ca. $1: 300 \mathrm{i}$ den norske befolkning. Det finnes 12 ulike subtyper av syndromet, og penetransen er variabel. Behandlingen er i hovedsak betablokker og implantasjon av hjertestarter.

Ny forskning åpner nå for muligheten til en mer skreddersydd behandling (1). En israelsk forskergruppe benyttet fibroblaster fra en pasient med lang QT-syndrom og laget en cellelinje, som så ble påvirket ved ulike molekylærgenetiske metoder slik at cellene ble stamcelleliknende. Man så da at disse cellene oppførte seg på samme måte som cellene i pasientens hjerte.

- Forskerne tok altså en celle fra en kvinne med syndromet og laget pluripotente stamceller fra denne ved å sette in tre gener, sier professor Jan P. Amlie ved Oslo universitetssykehus, Rikshospitalet. - Deretter laget de kardiomyocytter fra de pluripotente stamcellene ved styrt differensiering. Disse hjertecellene hadde, akkurat som pasienten, lang QT-tid og lett for å utvikle rytmeforstyrrelser. Forskerne brukte deretter dette modellsystemet for å teste hvilke impulser som stimulerte til rytmeforstyrrelser, og hvilke medikamenter som kunne bedre og eventuelt forverre tilstanden, sier han.

- Det er forventet at slike induserte pluripotente stamceller vil etablere et nytt paradigme for undersøkelser av sykdomsmekanismer og medikamentell behandling hos pasienter med genoverførte sykdommer. En forskergruppe i Oslo, med Jan Brinchmann i spissen, kan delta i et slikt arbeid, sier Jan P. Amlie.

\section{Åslaug Helland \\ aslaug.helland@gmail.com \\ Tidsskriftet}

\section{Litteratur \\ Itzhaki I, Maizels L, Huber I et al. Modelling the long QT syndrome with induced pluripotent stem cells. Nature 2011; doi: 10.1038/nature09747.}

VERDENS HELSE

\section{Færre dør av malaria på Zanzibar}

Forekomsten av malaria ser ut til

å være betydelig redusert på Zanzibar etter at man oppskalerte kontrolltiltakene i 2004

Fra 2004 er det på Zanzibar blitt gjennomført et malariakontrollprogram med fire tiltak: behandling med kombinasjonspreparater som inneholder artemisinin, distribuering av myggnett innsatt med insekticid, spraying av hus med insekticider og preventiv legemiddelbehandling (sulfadoksinpyrimetamin) av gravide. Dette ser ut til å ha gitt en betydelig reduksjon i forekomsten av malaria, ifølge en ny studie (1).

Journalgjennomgang ved seks av de sju sykehusene på øya viste en reduksjon i antall malariarelaterte dødsfall på $90 \%$ (95\% KI 55-98\%) og i antall innleggelser på $78 \%(95 \% \mathrm{KI} 48-90 \%)$ i perioden fra 1999-2003 til 2008. Andelen dødsfall forårsaket av malaria ble redusert fra $46 \%$ til $12 \%$ hos barn under fem år og fra $52 \%$ til $4 \%$ hos dem over fem år. I endemiske områder vil en stor andel av anemitilfellene skyldes malaria, og antall innleggelser pga. anemi falt med $87 \%$ (95\% KI 57-96\%), parallelt med reduksjonen i malaria. At den bedrede overlevelsen virkelig kunne tilskrives reduksjon i malariaforekomsten, ble støttet av at andelen positive prøver sank fra $37,5 \%$ av alle undersøkte mikroskopiske preparater til 0,6\%, som er en reduksjon på $99,5 \%$ (95\% KI 92-99,9\%).

Gode resultater har man også oppnådd med tilsvarende programmer $\mathrm{i}$ andre subsahariske land som Zambia, EkvatorialGuinea, Rwanda, Etiopia, i øystaten São Tomé og Príncipe og i Gambia. Effekten av programmene er oppløftende, men forfatterne advarer mot at gjenoppblomstring av malaria kan skje, slik det gjorde på Zanzibar etter at man hadde redusert malariaforekomsten ved bruk av DDT i 1970-årene.

\section{Kristoffer Brodwall}

kristoffer.brodwall@gmail.com

Barneklinikken

Haukeland universitetssykehus

\section{Litteratur}

1. Aregawi MW, Ali AS, Al-Mafazy AW et al. Reductions in malaria and anaemia case and death burden at hospitals following scale-up of malaria control in Zanzibar, 1999-2008. Malaria Journal 2011; 10: 46.
Nytt angrepsmål for terapi ved gastrointestinal tumor?

\section{Pasienter med gastrointestinal}

stromal tumor uten kjente muta-

sjoner kan ha mutasjon i genet for suksinatdehydrogenase.

Gastrointestinal stromal tumor er den vanligste mesenkymale neoplasmen i mage-tarm-kanalen. Den er resistent mot kjemoterapi. Mange av svulstene har mutasjoner i genene KIT eller PDGFRA, og behandling med småmolekylære inhibitorer av muterte KIT- og PDGFRA-proteiner har revolusjonert behandlingen og prognosen for disse pasientene. Men mange gastrointestinale stromale tumorer, særlig hos barn, mangler slike mutasjoner, og målrettet terapi har derfor liten effekt.

Det arvelige Carney-Stratakis' syndrom, som skyldes mutasjon i genet for suksinatdehydrogenase $(S D H)$, innebærer risiko for utvikling av gastrointestinal stromal tumor og paragangliom. I en internasjonal studie med 34 pasienter med gastrointestinal stromal tumor uten KITog PDGFRA-mutasjoner hadde fire mutasjon i varianter av $S D H$-genet, og alle de 34 pasientene hadde redusert proteinuttrykk av suksinatdehydrogenase (1).

- Forfatterne anbefaler at pasienter med gastrointestinal stromal tumor uten KIT- eller PDGFRA-mutasjoner bør testes for mutasjon i $S D H$-genet, sier overlege Kirsten Sundby Hall, som er leder for sarkomprogrammet ved Oslo universitetssykehus, Radiumhospitalet.

- Det kan være viktig å få avklart om en pasient med gastrointestinal stromal tumor har Carney-Stratakis' syndrom. Før man opererer disse pasientene for eventuelt tilbakefall av gastrointestinal stromal tumor må de undersøkes for hormonproduserende paragangliom. Alvorlige komplikasjoner kan oppstå under en slik operasjon. PET-CT kan brukes for å påvise begge tumortypene. Ved å identifisere genmutasjoner ved gastrointestinal stromal tumor kan man lettere kunne fremstille ny målrettet terapi, sier Sundby Hall.

\section{Åslaug Helland \\ aslaug.helland@gmail.com \\ Tidsskriftet}

\section{Litteratur}

Janeway KA, Kim SY, Lodish M et al. Defects in succinate dehydrogenase in gastrointestinal stromal tumors lacking KIT and DGFRA mutations. Proc Natl Acad Sci USA 2011; 108 $314-8$ 